\title{
Microbial food web in an oligotrophic high mountain lake (Jöri Lake III, Switzerland)
}

\author{
Brigitte HINDER $^{1)}$, Isabel BAUR, Kurt HANSELMANN ${ }^{1)}$ and Ferdinand SCHANZ* \\ University of Zürich, Institute of Plant Biology, Dept. of Limnology, Seestr. 187, CH-8802 Kilchberg, Switzerland \\ ${ }^{1)}$ University of Zürich, Institute of Plant Biology, Dept. of Microbiology, Zollikerstr. 107, CH-8008 Zürich, Switzerland \\ *e-mail corresponding author: fschanz@ botinst.unizh.ch
}

\begin{abstract}
Jöri Lake III (2512 $\mathrm{m}$ a.s.l., $\left.z_{m}=22 \mathrm{~m}, A=57.81 \times 10^{3} \mathrm{~m}^{2}, \mathrm{~V}=601.1 \times 10^{3} \mathrm{~m}^{3}\right)$ is situated in the Vereina region in the eastern part of the Swiss Alps. We studied microbial grazing on bacteria and bacterial productivity during the ice-free period. The lake normally gets thermally stratified for two months between July and September. In 1996, chlorophyll-a concentrations varied from 0.5 to $2.0 \mu \mathrm{g} l^{-1}$ with maximum values just below the thermocline ( $6 \mathrm{~m}$ depth), in 1997, they were between 0.6 and $5.0 \mu \mathrm{g} l^{-1}$ with maximum values at $10 \mathrm{~m}$ depth - several meters below the thermocline. Bacterial densities varied between 0.7 and $1.7 \times 10^{6} \mathrm{ml}^{-1}$ with maxima in the thermocline, one to two meters above the chlorophyll maximum. The areal bacterial biomass (volume beneath $1 \mathrm{~m}^{2}$ to a depth of $8 \mathrm{~m}$ ) was $10 \mu \mathrm{g} \mathrm{Cl} l^{-1}$ which remained more or less constant for the periods investigated. In 1997, bacterial growth rate and production rates were determined using $\left[{ }^{3} \mathrm{H}\right]$-thymidine incorporation. The rates were as low as 0.002 to $0.006 \mathrm{~h}^{-1}$ and 0.01 to $0.03 \mu \mathrm{g} C$ $l^{-1} h^{-1}$, respectively. We found a carbon ratio of bacteria, phytoplankton, and autotrophic picoplancton (APP) of 1.5:1.1:1 which shows a rather high abundance of bacteria and autotrophic picoplankton (APP) compared to larger phytoplankton. Bacterial growth followed a temperature dependence similar to the one observed for bacteria from Lake Zürich, a prealpine and mesotrophic lake which was studied for comparison. Microbial food web in Jöri Lake III was not top down controlled during the periods of our study and mixotrophic algae like Dinobryon cylindricum var. alpinum and autotrophic nanoflagellates (ANF) were the dominant bacterial grazers observed.
\end{abstract}

Key words: alpine lake, microbial food web, bacterial growth rates, autotrophic picoplankton, mixotrophic algae

\section{INTRODUCTION}

Productivity and nutrient cycling in high mountain ecosystems are governed by the extremely variable meteorological conditions. One of the characteristics of high mountain lake ecosystems is the long period of ice cover which may persists from October to July. High mountain lakes normally have low concentrations of nutrients as long as the drainage area is not fertilized and no wastewater is released to the catchment (Niederhauser 1993; Mez et al. 1998). In some lakes the nutrient budget is further affected by high turbidity due to suspended erosion particles from nearby glaciers. These inorganic particles can adsorb nutrients and affect the nutrient balance of the entire lake. Moreover, organic and inorganic matter transported over long distances as dust via the atmosphere from highly fertilized agricultural land can carry substantial amounts of nutrients with it (Schanz 1984). Suspended particles not only diminish light penetration, they also change the light quality thereby affecting growth and composition of the phototrophic plankton (Wyman \& Fay 1986; Glover et al. 1987; Talling 1971).

Primary production is low in oligotrophic high mountain ecosystems (Tilzer 1972) and low productivity of bacterial biomass is expected as well since the heterotrophic bacterial production depends on the re- lease of oxidizable organic carbon by photosynthetic organisms (Vrede 1996; Laybourn-Parry \& Walton 1998). This was found by Tilzer (1972) in the Vorderer Finstertaler Lake (Austria), and it was reported for ultraoligotrophic Antarctic lakes (Laybourn-Parry et al. 1995). There is a contradiction in reports which state that the significance of bacteria increases at low primary productivity and that bacterial production can temporarily exceed primary production (Scavia \& Laird 1987; Lavandier 1990; Coveney \& Wetzel 1995). This implies that the ratio of phytoplankton and bacterial biomass depends on other sources of organic carbon than exudates of phytoplankton. In oligotrophic lakes, bottom-up forces are strong compared to top-down grazing control. Algal taxa capable of mixotrophic modes of nutrition become more important and replace heterotrophic nanoflagellates (HNF) and ciliates in the foodweb (Jones 1994). Similarly, the importance of autotrophic picoplankton (APP) is expected to increase in nutrient-limited habitats, since small organisms have a higher surface to volume ratio than larger phytoplankton species. One might expect $40-60 \%$ of the total phytoplankton carbon being contributed by APP in oligotrophic ecosystems (Stockner 1991).

The scientific interest in the limnology of the Jöri lakes dates back to the beginning of the century. Kreis (1921) studied the fauna in 13 Jöri lakes and ponds and described the morphology of the lakes for the first time. 
When Messikommer investigated the phytoplankton in lakes of the Davos region in 1942, he included two of the Jöri lakes (Messikommer 1942). Renewed interest in studying the Jöri lakes emerged in connection with investigations on climate change impacts on the hydrological cycle in mountain regions. Comprehensive physical, hydrological, chemical and biological studies have been conducted in the Jöri catchment since 1996 (Hinder et al. 1999).

In the frame of the European Project MOLAR (Mountain Lake Research, Patrick et al. 1998) the dynamics of the bacterioplankton was investigated in Jöri Lake III. We studied growth and loss rates of heterotrophic bacteria in order to understand the significance of the microbial loop in oligotrophic lakes as outlined by Azam et al. (1983) for sea ecosystems. Lake Zürich was investigated to check the methodology of the determination of the bacterial production.

\section{STUDY SITE}

Jöri Lake III is one of 21 small lakes and ponds situated at elevations between 2489 and $2730 \mathrm{~m}$ a.s.l. in the Vereina region in eastern Switzerland. Crystalline rocks dominate in the drainage area. All lakes get formed as the Jöri Glacier retreats. Today, the glacier ends several hundred meters behind Lake III but turbid glacial erosion water percolates through the front moraine and enters the lake at subsurface springs. Lake III has a maximal depth of $22 \mathrm{~m}$. The water level is highest during the ice and snow melt period and falls continuously by up to $3 \mathrm{~m}$ during fall and early winter. The maximal surface area and volume are $57,810 \mathrm{~m}^{2}$ and $601,100 \mathrm{~m}^{3}$, respectively. Surface temperatures may reach $15^{\circ} \mathrm{C}$ in August when a stable thermocline gets established. The high concentration of suspended erosion particles creates turbidity which causes strong light attenuation. In August $1996 \mathrm{~K}_{\mathrm{d}}$ was $0.5 \mathrm{~m}^{-1}$, in July and August 1997 it was 0.6 $\mathrm{m}^{-1}$. Alkalinity and $\mathrm{pH}$ were 65 to $80 \mu \mathrm{eq} \mathrm{l}^{-1}$ and 6.4 to 6.9 , respectively, during the sampling periods. Conductivity $\left(25^{\circ} \mathrm{C}\right)$ was 14 to $20 \mu \mathrm{S} \mathrm{cm}^{-1}$, total phosphorous $<0.7 \mu \mathrm{M}$, and total organic carbon $0.7 \mathrm{mg} \mathrm{C}^{-1}$. The algal division Chlorophyta (e.g. Eutetramorus fottii, Dictyosphaerium subsolitarium, Monoraphidium subclavatum) represents the major fraction of the total phytoplankton biomass in Jöri Lake III (Hinder et al. 1999, this issue). There are also representatives of the divisions Chrysophyta (e.g. Dinobryon cylindricum var. alpinum, Kephyrion doliolum), and Cryptophyta (e.g. Rhodomonas lacustris). It is striking but ecologically meaningful that some of them are flagellates and potentially mixotrophic: e.g. Dinobryon cylindricum var. alpinum and Kephyrion doliolum. The lake is regularly stocked with fish (Salvelinus namaicush, Salmo trutta var. fario). The zooplankton community is dominated by rotatoria (Polyarthra sp. and Keratella sp.). Copepoda (Arctodiaptomus alpinus and Cyclops abyssorum var. tatricus) are also abundant, while Chydorus sphaericus is very scarce (pers. comm. J. Fott \& J. Cejkova).

\section{MATERIAL AND METHODS}

\subsection{Sampling}

Samples in Jöri Lake III were taken at the location of maximum depth with a 3 liter home-made plexiglass sampler (Charles University, Prague) from July to October 1996 and in July and August 1997. Alkalinity, pH, and total phosphorus were determined as described by Niederhauser (1993). Chlorophyll- $a$ (chl- $a$ ) concentration was measured using the fluorometric determination after Schanz (1982). Bacterial numbers in Jöri Lake III were determined in layers from the surface to $8 \mathrm{~m}$ depth ( $63 \%$ of the total water volume). Due to the large number of erosion particles it was difficult to recognize the bacterial cells in deep layers.

\subsection{Bacterial and autotrophic picoplankton (APP) densities and biomass}

Bacteria samples were fixed with glutaraldehyde ( $2 \%$ final concentration, v/v) immediately after sampling and stored in $50 \mathrm{ml}$ polyethylene bottles at $4^{\circ} \mathrm{C}$ in the dark. Bacteria were stained with DAPI (final concentration 1 - $1.5 \mathrm{mg} \mathrm{l}^{-1}$; Porter \& Feig 1980), filtered through membrane filters $(25 \mathrm{~mm}$ diameter, $0.2 \mu \mathrm{m}$ pore size) and counted using an epifluorescence microscope (Leitz Dialux 20, objective 100x). For the samples collected in 1996 Anodisc filters (Whatman, U.K., Nr. 6809 6022) and for the 1997-samples Black Nuclepore filters (Costar, U.S.A., Nr. 8242) were used. Anodisc filters were shown to give up to $30 \%$ higher cell counts (Jones et al. 1989). At least 400 cells were counted in eight or more randomly chosen grids. Bacterial volume was estimated by semi-automatic image analysis (Psenner 1993). An allometric model was used (Loferer-Kroessbacher et al. 1998) for the conversion of measured biovolumes (in $\mu \mathrm{m}^{3} \mathrm{l}^{-1}$ ) to biomass (in $\mathrm{mg} \mathrm{C}$ $\left.1^{-1}\right)$. For studies on short time dynamics of the bacterial population, we sampled at six depths every three hours over several days during the period from July to September 1996. APP-counting was performed by flow cytometry with samples collected in August and October 1996. For this purpose samples were first filtered through a $50 \mu \mathrm{m}$-net, $1.5 \mathrm{ml}$ of the filtered sample were then fixed in a $2 \mathrm{ml}$ cryotube with $150 \mu \mathrm{l}$ of a paraformaldehyde/glutaraldehyde solution (Marie et al. 1996) and stored at $-80{ }^{\circ} \mathrm{C}$ until analyzed. The analysis was carried out at the Biological Station in Roscoff (F). The APP biovolume was calculated from the counted cell numbers using an estimated cell diameter of $2 \mu \mathrm{m}$ (average value for eukaryotic picoplankton, Reynolds 1984). The biovolume was transformed to carbon using

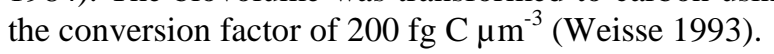




\subsection{Phytoplankton biomass}

For Jöri Lake III, phytoplankton biomass was calculated from the micro- and nanophytoplankton biovolumes (Hinder et al. 1999, this issue).

\subsection{Bacterial activity and bacterial production rate}

The $\left[{ }^{3} \mathrm{H}\right]$ thymidine method (rate of $\left[{ }^{3} \mathrm{H}\right]$ thymidine incorporation, pmol $\mathrm{l}^{-1} \mathrm{~h}^{-1}$ ) described in detail by Straškrabová et al. (1999, this issue) was used. To convert the $\left[{ }^{3} \mathrm{H}\right]$ thymidine-incorporation rate $\left(\mathrm{pmol} \mathrm{l}^{-1} \mathrm{~h}^{-1}\right)$ into cell production rate (cells $\mathrm{l}^{-1} \mathrm{~h}^{-1}$ ), a factor of $2 \times 10^{6}$ (cells pmol $^{-1}\left[{ }^{3} \mathrm{H}\right]$ thymidine) was used for Jöri Lake III samples (Bell 1990). Cell production rate was converted to bacterial production rate (in $\mu \mathrm{g} \mathrm{C}^{-1} \mathrm{~h}^{-1}$ ) using the allometric model factors $\left(\mu \mathrm{g} \mathrm{C}\right.$ cell $\left.^{-1}\right)$ determined for Jöri Lake III after Loferer-Kroessbacher et al. (1997).

\subsection{Specific bacterial growth and loss rate}

The specific bacterial growth rate $\mu\left(\mathrm{h}^{-1}\right)$ was calculated based on the number of cells produced $\Delta \mathrm{N}$ (cells $\mathrm{l}^{-1}$ ) during the incubation time $\mathrm{t}$, and the cell concentration at the beginning $\mathrm{N}_{0}$ (cells $\mathrm{l}^{-1}$ ) as:

$$
\mu=\mathrm{t}^{-1} \times \ln \left(1+\left(\Delta \mathrm{N} \times \mathrm{N}_{0}^{-1}\right)\right)
$$

Alternatively, specific bacterial growth was determined by the dilution culture method after Painchaud $e t$ al. (1996). Two cultures from each water sample are needed: $750 \mathrm{ml}$ of undiluted sample, and $750 \mathrm{ml}$ of a mixture (1:4) of undiluted sample and $0.2-\mu \mathrm{m}$-filtered water were incubated for $66 \mathrm{~h}$ at the sampling depth. Each experiment was sampled five times. From the net growth rates, $\mu_{\text {net }}$, of each sample one calculates gross growth and loss rates, $\mu_{\text {gross }}$ and $\nu$, respectively. At the same time, a second experiment was carried out replacing the untreated water by $3-\mu \mathrm{m}$-filtered water in order to measure loss rates caused by grazers $<3 \mu \mathrm{m}$ and autolysis.

\section{RESULTS}

\subsection{Bacterial morphology, biomass and abundance}

In 1996 Jöri Lake III began to stratify in July. At the beginning and at the end of August the depth profiles of temperature and chl- $a$ concentration were not subjected to daily changes (Fig. 1). During this period, bacterial

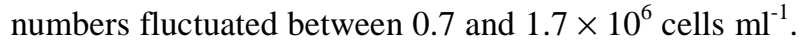
A pronounced maximum was found between 4 and $6 \mathrm{~m}$ in the thermocline. On August 22 this maximum was displaced from $5 \mathrm{~m}$ at 7 a.m. to $4 \mathrm{~m}$ at 1 p.m., and back to $5 \mathrm{~m}$ by 7 p.m. Temperature changed up to $1^{\circ} \mathrm{C}$ in the depth interval from 4 to $6 \mathrm{~m}$ which points to activities of internal seiches. Chl- $a$ concentrations varied between 0.5 and $2.0 \mu \mathrm{g} \mathrm{l}^{-1}$. Its maximum was at the bottom of the thermocline in $6 \mathrm{~m}$ depth, usually $1 \mathrm{~m}$ below the maximum of the bacteria. By the beginning of September the thermocline and stratification of bacteria and chl- $a$ had vanished.
The differences of the areal bacterial concentration (integral over the depth interval from 0 to $8 \mathrm{~m}$, in cells $\mathrm{m}^{-2}$ ) determined in three hour-intervals on ten days between July and September 1996 fluctuated between 0.06 and $+0.04 \mathrm{~h}^{-1}$ but the so calculated net growth rates were insignificant at the 5\%-confidence level. For two dates, August 9 (between 7 a.m. and 10 a.m.) and September 10 (between 1 p.m. and 4 p.m.) statistically significant net growth rates could be determined as $\mu_{\text {net }}=$ $0.06 \pm 0.03 \mathrm{~h}^{-1}$ and $\mu_{\text {net }}=-0.06 \pm 0.02 \mathrm{~h}^{-1}$, respectively.

The bacterial biomass at depths between 0 and $8 \mathrm{~m}$ was $12 \pm 2.3 \mu \mathrm{g} \mathrm{Cl}^{-1}(\mathrm{n}=4)$ during the ice free period of 1996. Bacteria were rod-shaped and rather small (0.028-0.034 $\mu^{3}$ cell $^{-1}$ ) (Tab. 1). Their mean cellular C-content was $10.9 \mathrm{fg} \mathrm{C}^{-1}$ cell $^{-1}$.

\subsection{Bacterial activity, growth and loss rates}

Due to the late ice melt, Jöri Lake III was only weakly stratified on the sampling days in July and August 1997 (Fig. 2). Bacterial densities, specific growth rates, and production rates did not differ significantly at the depths considered. Bacterial numbers were between 6.1 and $8.1 \times 10^{5}$ cells $\mathrm{ml}^{-1}$. The specific growth rates varied between 0.002 to $0.006 \mathrm{~h}^{-1}$ and only very low amounts of $\left[{ }^{3} \mathrm{H}\right]$ thymidine were assimilated. Two out of ten samples showed uptake rates which differed significantly from zero ( $t$-test, $\mathrm{P}<0.02)$, the ones determined for July 29 at $6 \mathrm{~m}$ and the ones from August 7 at $1 \mathrm{~m}$ depth. For both cases a bacterial growth rate of $0.003 \mathrm{~h}^{-1}$ was calculated resulting in production rates between 0.01 and $0.03 \mu \mathrm{g} \mathrm{Cl}^{-1} \mathrm{~h}^{-1}$. The bacterial growth and loss rates determined by the dilution culture method were equal in the non filtered samples and in a fraction after filtering through $3 \mu \mathrm{m}$ pore-size filters. The values were $0.008 \pm 0.002 \mathrm{~h}^{-1}$ which is the same order of magnitude as the values found with $\left[{ }^{3} \mathrm{H}\right]$ thymidine incorporation.

\subsection{Phytoplankton biomass and abundance}

The phytoplankton biomass (without autotrophic picoplankton) at depths from 4 to $5 \mathrm{~m}$ during the ice free period in 1996 amounted to $9.1 \pm 0.5 \mu \mathrm{g} \mathrm{C}^{-1}(\mathrm{n}=3)$. The flow cytometric analyses of the APP showed red $(>650 \mathrm{~nm})$ but almost no orange $(585 \times 21 \mathrm{~nm})$ cell fluorescence. This suggests that the Jöri Lake III APP consisted mostly of eukaryotic algae while cyanobacteria represented a minor portion of the phytoplankton community. The cell density of APP was $1.0 \times 10^{4}$ cells $\mathrm{ml}^{-1}$ in the average with a maximum at the same depth as the chl- $a$ maximum. In August 1996, the calculated average APP biomass for the depth 4 to $5 \mathrm{~m}$ was $8 \mu \mathrm{g} \mathrm{C}$ $1^{-1}$.

\section{DISCUSSION}

Although the bacterial growth rates determined by the $\left[{ }^{3} \mathrm{H}\right]$ thymidine method show considerable uncer- 


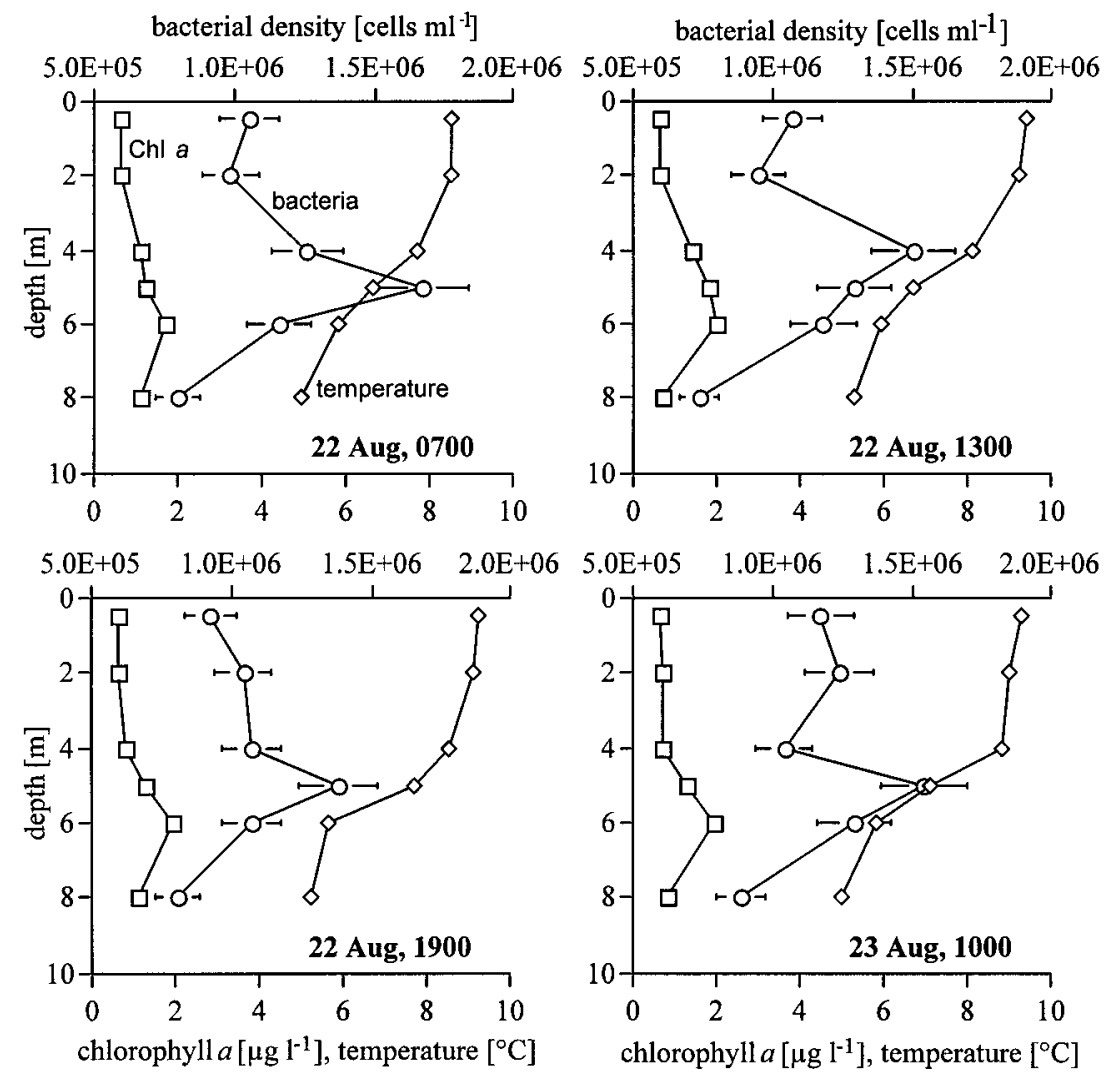

Fig. 1. Profiles of chlorophyll- $a$ - concentration, temperature and bacterial density during a daily cycle on August $22^{\text {nd }}$ and $23^{\text {rd }}, 1996$ in Jöri Lake III. Bars are $95 \%$ confidence intervals of the means of bacterial density.

Tab. 1. Average length, width, volume and C-content of bacteria from Lake Zürich and Jöri Lake III in 1997. $\mathrm{n}$ is the number of measured cells, $\overline{\mathrm{x}}$ is the mean and $\overline{\mathrm{x}}_{\mathrm{s}}$ the standard error.

\begin{tabular}{|c|c|c|c|c|c|c|c|c|c|c|}
\hline \multicolumn{3}{|c|}{ sample } & \multicolumn{2}{|c|}{$\begin{array}{l}\text { length } \\
(\mu \mathrm{m})\end{array}$} & \multicolumn{2}{|c|}{$\begin{array}{l}\text { width } \\
(\mu \mathrm{m})\end{array}$} & \multicolumn{2}{|c|}{$\begin{array}{c}\text { volume } \\
\left(\mu \mathrm{m}^{3} \text { cell }^{-1}\right)\end{array}$} & \multicolumn{2}{|c|}{$\begin{array}{c}\text { C-cont. } \\
\left(\text { fg C cell }^{-1}\right)\end{array}$} \\
\hline date & depth & $\mathrm{n}$ & $\overline{\mathrm{X}}$ & $\overline{\mathrm{x}}_{\mathrm{s}}$ & $\overline{\mathrm{X}}$ & $\overline{\mathrm{x}}_{\mathrm{s}}$ & $\overline{\mathrm{X}}$ & $\overline{\mathrm{x}}_{\mathrm{s}}$ & $\overline{\mathrm{x}}$ & $\overline{\mathrm{x}}_{\mathrm{s}}$ \\
\hline 29 July & $2 \mathrm{~m}$ & 447 & 0.470 & 0.009 & 0.305 & 0.003 & 0.028 & 0.001 & 10.2 & 0.3 \\
\hline \multirow[t]{2}{*}{31 July } & $1 \mathrm{~m}$ & 557 & 0.618 & 0.017 & 0.292 & 0.003 & 0.034 & 0.001 & 12.1 & 0.3 \\
\hline & $5 \mathrm{~m}$ & 495 & 0.537 & 0.014 & 0.281 & 0.003 & 0.028 & 0.001 & 10.0 & 0.3 \\
\hline 7 Aug & $2 \mathrm{~m}$ & 662 & 0.544 & 0.022 & 0.304 & 0.003 & 0.033 & 0.001 & 11.5 & 0.3 \\
\hline
\end{tabular}

tainty due to the low incorporation rates, they indicate the order of magnitude. They were all in the same range which was also confirmed by the dilution culture results. To check the reliability of the results, we did the same experiments in the prealpine, mesotrophic Lake Zürich (unpublished results). As expected, we found higher specific growth rates $\left(0.008\right.$ to $\left.0.044 \mathrm{~h}^{-1}\right)$ with lower standard errors $(9 \%, \mathrm{n}=3)$. The reliable results obtained with the $\left[{ }^{3} \mathrm{H}\right]$ thymidine method for Lake Zürich give evidence that the high uncertainty of the Jöri Lake III results was not caused by methodological errors but rather by sensitivity of the $\left[{ }^{3} \mathrm{H}\right]$ thymidine method when applied to the low bacterial activity in Jöri Lake III.
The carbon ratio of bacteria, phytoplankton, and autotrophic picoplankton (APP) was 1.5:1.1:1, a rather high abundance of bacteria and APP compared to larger phytoplankton. This result corroborates observations by Simon et al. (1992) for different lakes and it allows to conclude that bacterial biomass and phytoplankton biomass are in the same order of magnitude when phytoplankton biomass is low. The biomass of larger phytoplankton and the APP biomass were approximately the same in Jöri Lake III. This confirms that APP have a selective advantage in oligotrophic environments which is due to their high surface to volume ratio (Stockner 1991). Nevertheless, APP and in particular picocyanobacteria are generally negligible in mountain lakes due 


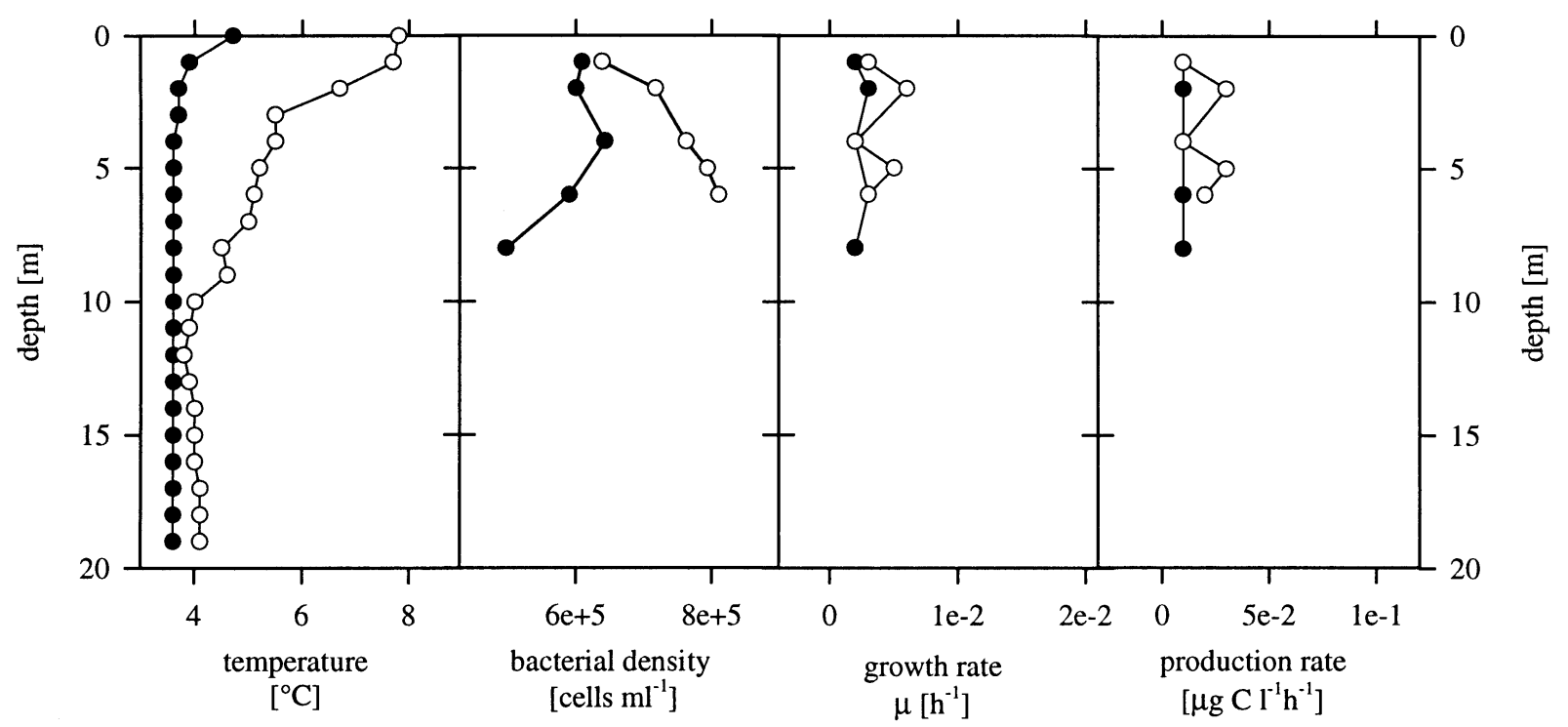

Fig. 2. Profiles of temperature (A), bacterial density (B), specific growth rate $\mu$ (C), and bacterial production rate (D) for Jöri Lake III and Lake Zürich in 1997. Squares for Jöri Lake III (closed symbols- July $29^{\text {th }}$; open symbols-August $7^{\text {th }}$ ) and circles for Lake Zürich (closed symbols- June $13^{\text {th }}$; open symbols-July $1^{\text {st }}$ ).

to photoinhibition. Jöri Lake III is an exception as the suspended erosion particles diminish the light penetration significantly and change the underwater light climate.

In Jöri Lake III, APP might contribute an important part of extracellular carbon, from which bacteria can profit. An the other hand, the rather high TOC content suggests that allochthonous input of organic carbon might be a major $\mathrm{C}$-source for heterotrophic growth. Since TOC is $0.7 \mathrm{mg} \mathrm{l}^{-1}$ and the sum of bacterial, APP and phytoplankton biomass is about $0.03 \mathrm{mg} \mathrm{C}^{-1}$, one might assume an allochthonous input of slowly degradable carbon from the watershed which could promote bacterial growth independently of extracellular carbon release by algae.

Bacterial production and loss rates were in balance during the sampling periods, since the loss rates did not differ significantly from the production rates. In Jöri Lake III the main grazers were smaller than $3 \mu \mathrm{m}$ which was in contrast to Lake Zürich. Similar results were reported for other eutrophic and mesotrophic systems (Šimek et al. 1997, Jürgens \& Güde 1991). Possible bacteria grazers are Daphnia species, protozoa (heterotrophic nanoflagellates HNF, ciliates), and mixotrophic algae like Dinobryon species or autotrophic nanoflagellates (ANF, Pace et al. 1990). Daphnia species were never observed in Jöri Lake III and HNF and ciliates are very scarce $\left(<28\right.$ cells $\mathrm{ml}^{-1}$ and 0.04 cells $\mathrm{ml}^{-1}$, respectively; K. Šimek \& M. Macek, personal communication). Probably the most important bacterial grazers in Jöri Lake III are mixotrophic algae. Both, Dinobryon species and ANF were frequent in 1997 in Jöri Lake III with concentrations up to 50 cells ml ${ }^{-1}$ and 182 cells ml
1, respectively (K. Šimek, personal communication, B. Hinder, unpublished). This suggestion is supported by the observation that the maximum bacterial numbers were always found just above the chl- $a$ maximum within the thermocline. Since bacterial production is enhanced by the release of organic carbon from phytoplankton, bacteria are expected to be abundant where phytoplankton densities are high. Algae are not expected to release more organic carbon in upper layers as a consequence of photoinhibition, as the photosynthetic active radiation (PAR) at four meters depths amounts to $250 \mu \mathrm{E} \mathrm{m}^{-2} \mathrm{~s}^{-1}$ maximally. Bacterial numbers were low at the site of the chl-a-maximum where mixotrophic algae, the most important bacterial grazers, are most numerous. Since water densities are lower than biomass densities and since water density differences are small at low temperatures there are no physical reasons to justify why bacteria and phytoplankton prefer to accumulate in the thermocline of Jöri Lake III. UV-radiation is also of little importance for the vertical distribution of phytoand bacterioplankton at the depths where they are observed since the lake's turbidity prevents UV-radiation to reach deeper than $1 \mathrm{~m}$ below the surface. Mixotrophic algae seem to be the major players in the microbial loop of this ecosystem.

Temperature is about $2^{\circ} \mathrm{C}$ higher at depths where bacteria are most abundant compared to the depth of the chl-a-maximum (Fig. 2). The two pairs of data sets from Jöri Lake III (Fig. 3), obtained by the $\left[{ }^{3} \mathrm{H}\right]$ thymidine method, fit well into the Lake Zürich data, suggesting that the same temperature control might apply to bacterial growth in Jöri Lake III. It could not be shown, however, that slightly enhanced bacterial activity would lead 
to higher biomass production as observed in Lake Zürich where bacterial growth was clearly temperature dependent up to $22{ }^{\circ} \mathrm{C}$ with a $\mathrm{Q}_{10}$ of 3.2 (Fig. 3).

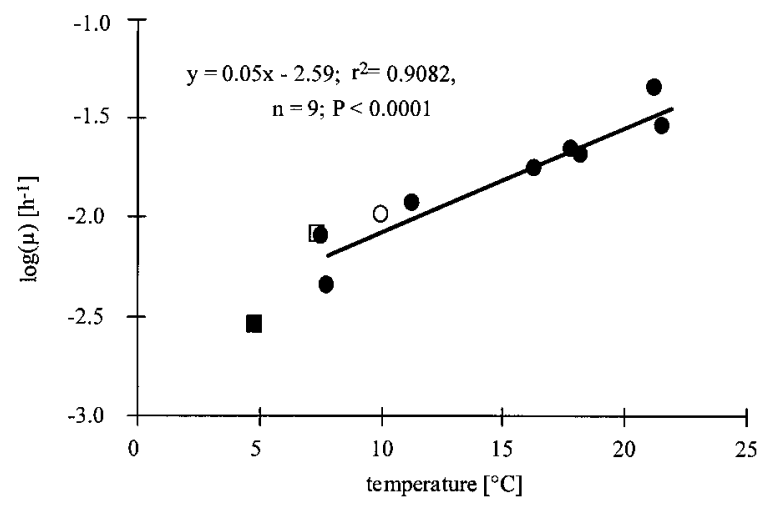

Fig. 3. Correlation between temperature and specific bacterial growth rates for Lake Zürich with two data points from Jöri Lake III for comparison. Circles represent Lake Zürich data, squares the Jöri Lake III data; open symbols are results obtained by the dilution culture method, closed symbols are results obtained by the [ ${ }^{3} \mathrm{H}$ ]thymidine method (for Jöri Lake III the averaged value of the statistically significant experiments are represented).

The measured bacterial production rates of 0.01 to $0.03 \mu \mathrm{g} \mathrm{C}^{-1} \mathrm{~h}^{-1}$ are in the same range as those found in a Spanish high mountain lake (Reche et al. 1996), where the primary production was 10 times the bacterial production $\left(0.2\right.$ to $\left.1.5 \mu \mathrm{g} \mathrm{C}^{-1} \mathrm{~h}^{-1}\right)$. For Jöri Lake III primary production differs from the one observed in the Spanish mountain lake since alkalinity, conductivity and phosphate concentrations are lower.

\section{CONCLUSIONS}

The microbial loop in Jöri Lake III is not mainly top down controlled since bacterial grazing is very low. The carbon ratio of bacteria, phytoplankton, and autotrophic picoplankton (APP) was 1.5:1.1:1 which shows a rather high abundance of bacteria and APP compared to larger phytoplankton. It emphasizes the importance of bacteria and APP in this oligotrophic, turbid lake. APP biomass was similar to the biomass of the larger phytoplankton. The high proportion of APP in the total phytoplankton biomass reflects the selective advantage of small organisms with a high surface to volume ratio in oligotrophic environments. Although, APP are generally negligible in mountain lakes due of photoinhibition, in the turbid Jöri Lake III they obviously find good conditions to propagate.

Bacterial growth could be enhanced by allochthonous organic carbon originating from the watershed, a source which would be available more constantly than extracellular organic carbon released by algae.

The taxa capable of both heterotrophic and autotrophic modes of nutrition become more important; in Jöri
Lake III it is interesting to note that purely heterotrophic nanoflagellates and ciliates are virtually absent. Our observations suggest that mixotrophic algae of the genus Dinobryon and other mixotrophic nanoflagellates are the major bacterial grazers. Their mode of nutrition must provide advantages for survival and competition in oligotrophic high mountain lakes.

\section{ACKNOWLEDGMENTS}

Research was supported through the project MOLAR, EU-No. ENV4-CT95-0007 of the EU Environment and Climate Programme, financed by the Ministry of Education and Science of Switzerland (Contract No. 95.0518-2) and by a grant from the Swiss National Science Foundation (CLEAR No. 5001-44614/1). We thank H.R. Preisig, Institute of Systematic Botany, University of Zurich, for helping with phytoplankton determination; V. Straškrabová, Hyrobiological Institute of the Czech Academy of Sciences, České Budějovice, for reading the manuscript; H.P. Schmidhauser, A. Birchmeier, D. Bollier and D. Högl for the operation of the mountain station; R. Psenner \& Th. Posch, University of Innsbruck, for the volumetric analysis of bacteria. K. Šimek \& M. Macek, Hyrobiological Institute of the Czech Academy of Sciences, České Budějovice, for the introduction to the $\left[{ }^{3} \mathrm{H}\right]$ thymidine technique and the protozoa data; D. Vaulot \& D. Marie, Biological Station of Roscoff (F) for the flow cytometry analyses; J. Fott \& J. Cejkova, Charles University of Prague, for zooplankton data.

\section{REFERENCES}

Azam, F., T. Fenchel, J.G. Field, J.S. Gray, L.A. Meyer-Reil \& F. Thingstad. 1983. The ecological role of water-column microbes in the sea. Mar. Ecol. Prog. Ser., 10: 257263.

Bell, R.T. 1990. An explanation for the variability in the conversion factor deriving bacterial cell production from incorporation of $\left[{ }^{3} \mathrm{H}\right]$-thymidine. Limnol. Oceanogr., 35: 910-915.

Button, D.K., B.R. Roberston, \& F. Jüttner. 1996. Microflora of a subalpine lake: bacterial populations, and their dependence on phosphate. Microb. Ecol., 21: 87-101.

Coveney, M.F. \& R.G. Wetzel. 1995. Biomass, production and specific growth rate of bacterioplankton and coupling to phytoplankton in an oligotrophic lake. Limnol. Oceanogr., 40: 1187-2000.

Ducklow, H.W., D.L. Kirchman \& H.L. Quinby. 1992. Determination of bacterioplankton growth rates during the North Atlantic spring phytoplankton bloom: Cell growth and macromolecular synthesis in seawater cultures. $M i$ crob. Ecol., 24: 125-144.

Glover, H.E., M.D. Keller \& R.W. Spinrad. 1987. The effects of light quality and intensity on photosynthesis and growth of marine eukaryotic and prokaryotic phytoplankton clones. J. Exp. Mar. Biol. Ecol., 105: 137-159.

Hinder, B., M. Gabathuler, B. Steiner, K. Hanselmann \& H. R. Preisig. 1999. Seasonal dynamics and phytoplankton diversity in high mountain lakes (Jöri lakes, Swiss Alps). In: Straškrabová, V., C. Callieri \& J Fott (Eds), Pelagic food web in mountain lakes. MOuntain LAkes Research Program. J. Limnol., 58(2): 152-161. 
Jones, R.I. 1994. Mixotrophy in planktonic protists as spectrum of nutritional strategies. Mar. Microb. Food Webs, 8: 87-96.

Jones, S.E., S.A. Ditner, C. Freeman, C.J. Whitaker \& M.A. Lock. 1989. Comparison of a new inorganic membrane filter (Anopore) with a track-etched polycarbonate membrane filter (Nuclepore) for direct counting of bacteria. Appl. Environ. Microbiol., 55: 529-530.

Jürgens, K. \& H. Güde. 1991. Seasonal changes in the grazing impact of phagotrophic flagellates on bacteria in lake Constance. Mar. Microb. Food Webs, 5: 27-37.

Kreis, H.A. 1921. Die Jöriseen und ihre postglaziale Besiedlungsgeschichte. Eine faunistisch-biologische Studie. Int. Rev. ges. Hydrobiol. Hydrograph., 9: 189-212, 241-288, 451-490.

Lavandier, P. 1990. Dynamics of bacterioplankton in a mesotrophic French reservoir. Hydrobiologia, 207: 79-86.

Laybourn-Parry, J. \& M. Walton. 1998. Seasonal heterotrophic flagellate and bacterial plankton dynamics in a large oligotrophic lake: Loch Ness, Scotland. Freshwat. Biol., 39(1): 1-8.

Laybourn-Parry, J., P. Bayliss, J. \& C. Ellis-Evans. 1995. The dynamics of heterotrophic nanoflagellates and bacterioplankton in a large ultra-oligotrophic Antarctic lake. $J$ Plankton Res., 17: 1835-1850.

Loferer-Kroessbacher, M., J. Klima \& R. Psenner. 1998. Determination of bacterial cell dry mass by transmission electron microscopy and densitometric image analysis. Appl. Envrion. Microbiol., 64: 688-694.

Marie, D., F. Pratensky, S. Jacquet \& D. Vaulot. 1996. Enumeration and cell cycle analysis of natural populations of marine picoplankton by flow cytometry using the nucleic acid stain SYBR Green I. Appl. Environ. Microbiol., 63: 186-193.

Messikommer, E. 1942. Beitrag zur Kenntnis der Algenflora und Algenvegetation des Hochgebirges um Davos. Beiträge zur geobotanischen Landesaufnahme der Schweiz, Heft 24. Verlag Hans Huber, Bern.

Mez, K., K. Hanselmann \& H.R. Preisig. 1998. Environmental conditions in high mountain lakes containing toxic benthic cyanobacteria. Hydrobiologia, 368: 1-15.

Niederhauser, P. 1993. Diatomeen als Bioindikatoren zur Beurteilung der Belastung elektrolytarmer Hochgebirgsseen durch Säuren und Nährstoffe. Ph.D.Thesis, University of Zürich: $110 \mathrm{pp}$.

Pace, M.L., G.B. McManus \& S.E.G. Findlay. 1990. Planktonic community structure determines the fate of bacterial production in a temperate lake. Limnol. Oceanogr., 35: 797-808.

Painchaud, J.D., D. Lefaivre, J.C. Therriault \& L. Legendre. 1996. Bacterial dynamics in the upper St. Lawrence estuary. Limnol. Oceanogr., 41: 1610-1618.

Patrick, S., R.W. Batterbee, B. Wathne \& R. Psenner. 1998. Measuring and modelling the dynamic response of remote mountain lake ecosystems to environmental change: an introduction to the MOLAR project. In: Kovar, U. Tappeiner, N.E. Peters \& R.G. Craig (Eds), Hydrology, water resources and ecology in headwaters. Proceedings of the HeadWater' 98 conference, Merano: 403-410. International Association of Hydrological Sciences Publ. No. 248, IAHS Press, Wallingford.

Porter, K.G. \& Y.S. Feig. 1980. The use of DAPI for identifying and counting aquatic microflora. Limnol. Oceanogr. 25: 943-948.

Psenner, R. 1993. Determination of size and morphology of aquatic bacteria by automated image analysis. In: P.
Kemp, B.F. Sherr \& E.B. Sherr, J. Cole (Eds), Handbook of Methods in Aquatic Microbial Ecology. Lewis Publishers, Boca Raton: 339-345.

Reche, L., A. Pugnetti, L. Cruz-Pizarro \& P. Carrillo. 1996. Relationship between bacteria and phytoplankton in a high-mountain lake: Importance of the organic carbon released by pelagic algae for bacterioplankton. Arch. Hydrobiol. Spec. Issues Advanc. Limnol., 48: 31-38.

Reynolds, C.S. 1984. The ecology of freshwater phytoplankton. Cambridge University Press, Cambridge.

Scavia, D. \& G.A. Laird. 1987. Bacterioplankton in Lake Michigan: Dynamics, controls and significance to carbon flux. Limnol. Oceanogr., 32: 1017-1033.

Schanz, F. 1982. A fluorimetric method of determining chlorophyll a and phaeophytin a concentrations. Arch. Hydrobiol. Beih. Ergeb. Limnol., 16: 91-100.

Schanz, F. 1984. Chemical and algological characteristics of five high mountain lakes near the Swiss National Park. Verh. Int. Ver. Limnol., 22: 1066-1070.

Schanz, F. 1985. Vertical light attenuation and phytoplankton development in Lake Zürich. Limnol. Oceanogr., 30: 299 310.

Šimek, K., P. Hartman, J. Nedoma, J. Pernthaler, D. Springmann, J. Vbra \& R. Psenner. 1997. Community structure, picoplankton grazing and zooplankton control of heterotrophic nanoflagellates in a eutrophic reservoir during the summer phytoplankton maximum. Aquat. Microb. Ecol., 12: 49-63.

Simon, M., B.C. Cho \& F. Azam. 1992. Significance of bacterial biomass in lakes and the ocean: comparison to phytoplankton biomass and biogeochemical implications. Mar. Ecol. Prog. Ser. 86: 103-110.

Stockner, J.G. 1991. Autotrophic picoplankton in freshwater ecosystems: The view from the summit. Int. Revue ges. Hydrobiol., 76: 483-492.

Straškrabová, V., C. Callieri, P. Carrillo, L. Cruz-Pizarro, J. Fott, P. Hartman, M. Macek, J.M. Medina-Sánchez, J. Nedoma \& K. Šimek. 1999. Investigations on pelagic food webs in mountain lakes - aims and methods. In: Straškrabová, V., C. Callieri \& J Fott (Eds), Pelagic food web in mountain lakes. MOuntain LAkes Research Program. J. Limnol., 58(2): 77-87.

Talling, J.F. 1971. The underwater light climate as a controlling factor in the production ecology of freshwater phytoplankton. Mitt. Int. Ver. Limnol.,19: 214-243.

Thomas, E.A. 1964. Katalog der Planktonorganismen des Zürich-Obersees und des Zürichsees. Vierteljahrsschr. Naturforsch. Ges. Zürich, 109: 103-142.

Tilzer, M. 1972. Dynamik und Produktivität von Phytoplankton und pelagischen Bakterien in einem Hochgebirgssee (Vorderer Finstertaler See, Österreich). Arch. Hydrobiol. Suppl., 40: 201-273.

Vrede, K. 1996. Regulation of bacterioplankton production and biomass in an oligotrophic clearwater lake- the importance of the phytoplankton community. J. Plankton Res., 18: 1009-1032.

Weisse, T. 1993. Dynamics of autotrophic picoplankton in marine and freshwater ecosystem, In: J.G. Jones (Ed.). Advances in microbial ecology, Plenum Press, New York, 13: 327-370.

Wyman, M. \& P. Fay. 1986. Underwater light climate and the growth and pigmentation of planktonic blue-green algae (Cyanobacteria). II. The influence of light quality. Proc. Roy. Soc. Lond., 227: 381-393. 